\title{
Profile of the Trypanosoma cruzi vector infestation in Jaboticatubas, State of Minas Gerais, Brazil
}

\author{
Carlota Josefovicz Belisário ${ }^{[1]}$, João Victor Leite Dias ${ }^{[1],[2]}$ and Liléia Diotaiuti ${ }^{[1]}$
}

[1]. Laboratório de Triatomíneos e Epidemiologia da Doença de Chagas, Centro de Pesquisas René Rachou, Fundação Oswaldo Cruz, Belo Horizonte, MG. [2]. Departamento de Farmácia, Laboratório de Doenças Parasitárias, Universidade Federal dos Vales do Jequitinhonha e Mucuri, Diamantina, MG.

\begin{abstract}
Introduction: This work aimed to analyze the triatomine infestation scenario in Jaboticatubas after 30 years of the uninterrupted actions of the Program of Chagas Disease Control. Methods: From 2007 to 2010, household unit infestation was researched, and an exploratory analysis of the localities infested with Panstrongylus megistus was performed. Results: In total, 613 triatomines were captured in 78 households, the majority of which were Panstrongylus megistus and were captured mainly in chicken houses, but they were also found to be colonizing human houses. Conclusions: The epidemiological importance of Panstrongylus megistus was confirmed in Jaboticatubas, and capability to colonize indoors has been demonstrated, as has its proximity to humans. Its distribution is aggregated in the northern and in central-eastern regions of the municipality.
\end{abstract}

Keywords: Panstrongylus megistus. Infestation. Spatial analysis.

Triatomines (kissing bugs, Hemiptera, Reduviidae, Triatominae) have epidemiological significance due to the capacity to transmit the etiologic agent of Chagas disease (CD), the flagellate protozoan Trypanosoma cruzi (Chagas 1909). Panstrongylus megistus (Burmeister 1835) is one of the most epidemiologically important species in Brazil ${ }^{1}$, occurring from the State of Maranhão to Rio Grande do Sul ${ }^{2}$, and it is also found in Bolivia, Paraguay, Uruguay and Argentina ${ }^{3}$. is responsible for the transmission of CD in large areas of the western region of Brazil ${ }^{4}$ and has a great capability to reinfest households from wild foci. Thus, inhabited areas require constant entomological surveillance 5 .

Spatial analysis is useful for determining the areas that require special attention in the face of a public health problem ${ }^{6}$. The Kernel density estimator may indicate the clustering of events, highlighting particular foci of high incidence ${ }^{7}$.

The region of Serra do Cipó, State of Minas Gerais, includes the Cities of Jaboticatubas, Santana do Riacho, Morro do Pilar, Itambé do Mato Dentro and Nova União and as a CD prevalence in the 80 s percentile, ranging from 6.5 to $25.2^{8}$, with the vector P. megistus responsible for transmitting the human disease. The Program of Chagas Disease Control (PCDC) has been active in this region since 1978, searching for foci and spraying insecticides in infested household units. This work aimed to analyze the triatomine infestation scenario in Jaboticatubas after 30 years of uninterrupted vector control activities.

\footnotetext{
Address to: Dra Lileia Diotaiuti. Lab. de Triatomíneos e Epidemiologia da Doença de Chagas/CPqRR/FIOCRUZ. Av. Augusto de Lima 1715, Barro Preto, 30190-002 Belo Horizonte, MG, Brasil.

Phone: 5531 3349-7762

e-mail: diotaiuti@cpqrr.fiocruz.br

Received 17 July 2012

Accepted 27 March 2013
}

Jaboticatubas has an area of $1,114,155 \mathrm{~km}^{2}$ and includes 237 localities, 10,554 households and a population of 17,134 inhabitants $(6,394 \text { people in rural areas })^{9}$.

The Municipal Secretariat of Health cooperated with the triatomine capture, which was conducted by active search according to the PCDC methodology ${ }^{10}$ from 2007 to 2010. The infested household units were sprayed with pyrethroid insecticide. The following entomological indexes were determined: a) infestation, number of houses infested with triatomines/number of examined houses x 100; b) density, number of captured triatomines/number of examined houses; c) dispersion, number of locations infested with triatomines/ number of examined locations x 100; and d) natural infection, number of triatomines with $T$. cruzi/number of examined triatomines $\times 100^{10}$. T. cruzi infection was determined by fresh stool examination using an optical microscope.

All locations visited were georeferenced to analyze the repartition of $P$. megistus captured in the house environment in Jaboticatubas. Georeferencing was performed based on the database of the Agricultural Census from the Brazilian Institute of Geography and Statistics (IBGE), and the locations that were not listed in this database were georeferenced in loco using a handheld Global Positioning System (GPS) unit (Garmin ${ }^{\mathrm{TM}}$ GPSMAP 76Cx, Olathe, Kansas 66062, USA).

Considering the epidemiological importance of P. megistus, an exploratory analysis of the locations infested with this species was conducted. Hotspot mapping was performed using the quartic function of the Kernel density estimator ${ }^{11}$. This function consists of a nonparametric technique that promotes the statistical smoothing of the event local density over the studied area, resulting in a surface area of risk occurrence, favoring the view of the phenomenon in focus ${ }^{6}$. For the Kernel estimator, a bandwidth of $2,500 \mathrm{~m}$ was considered the distance in which significant clustering among positive localities was detected 
using the $\mathrm{K}$ function ${ }^{11}$. Spatial analyses were performed using the SPRING 5.2 program.

Throughout the entire study, 159 localities $(67.1 \%$ of the total) were studied, of which $44(27.7 \%)$ were infested by triatomines (Figure 1). Three of the localities were infested in more than one cycle, always with P. megistus. Six hundred thirteen triatomines were captured in 78 households, 578 of which were $P$. megistus and 35 of which were Triatoma sordida. In all households, infestation was confirmed in only one place, except for one event, with simultaneous capture of triatomines in the barn, chicken house and bedroom. Reinfestation (IV and $\mathrm{V}$ nymphs found) by $P$. megistus was observed in a chicken house five months after the spraying of insecticide.

P. megistus was the species most frequently observed, with dispersion rates of 35.1 in 2007, 14.1 in 2008, 18.1 in 2009 and 15.7 in 2010 . The density rates ranged from 4.4 to 6.5 , but three large colonies were detected (58, 57 and 68 triatomines) associated with chicken nests.

The vast majority of $P$. megistus was detected around homes (92\%). The largest number was collected in chicken houses $(59.5 \%)$, followed by barns $(16.6 \%)$ and a warehouse. Inside the house, the insects were captured in the bedroom, except for one adult that was captured in the living room. Colonies (with nymphs) of $P$. megistus were captured mainly in chicken houses and bedrooms (Table 1).

Most of the houses $(94.1 \%, 48)$ had brick walls with plaster, and only three $(5.9 \%)$ had clay walls with plaster. All households examined had tile roofs.

Areas with greater occurrence rates of $P$. megistus infested localities (hotspots) were located mainly in the northern region; two were located in the central-eastern region (Figure 1). The eastern region coincides with the National Park of Serra do Cipó and is uninhabited.

Currently, the vector transmission of $\mathrm{CD}$ in Brazil is considered to be under control due to the actions of the $\mathrm{PCDC}^{12}$. In 1999, control actions were transferred to the municipalities ${ }^{13}$, and many have discontinued the PCDC activities. The City of Jaboticatubas continued with control tasks, performing active infestation research in more than $20 \%$ of its locations from 2007 to 2010 , which exceeds the actions recommended by the $\mathrm{PCDC}^{10}$.

The importance of $P$. megistus as a domiciliary vector was again demonstrated in Jaboticatubas because the species was mostly captured in bedrooms, indicating a risk of transmission to the inhabitants. An important fact is the discovery of

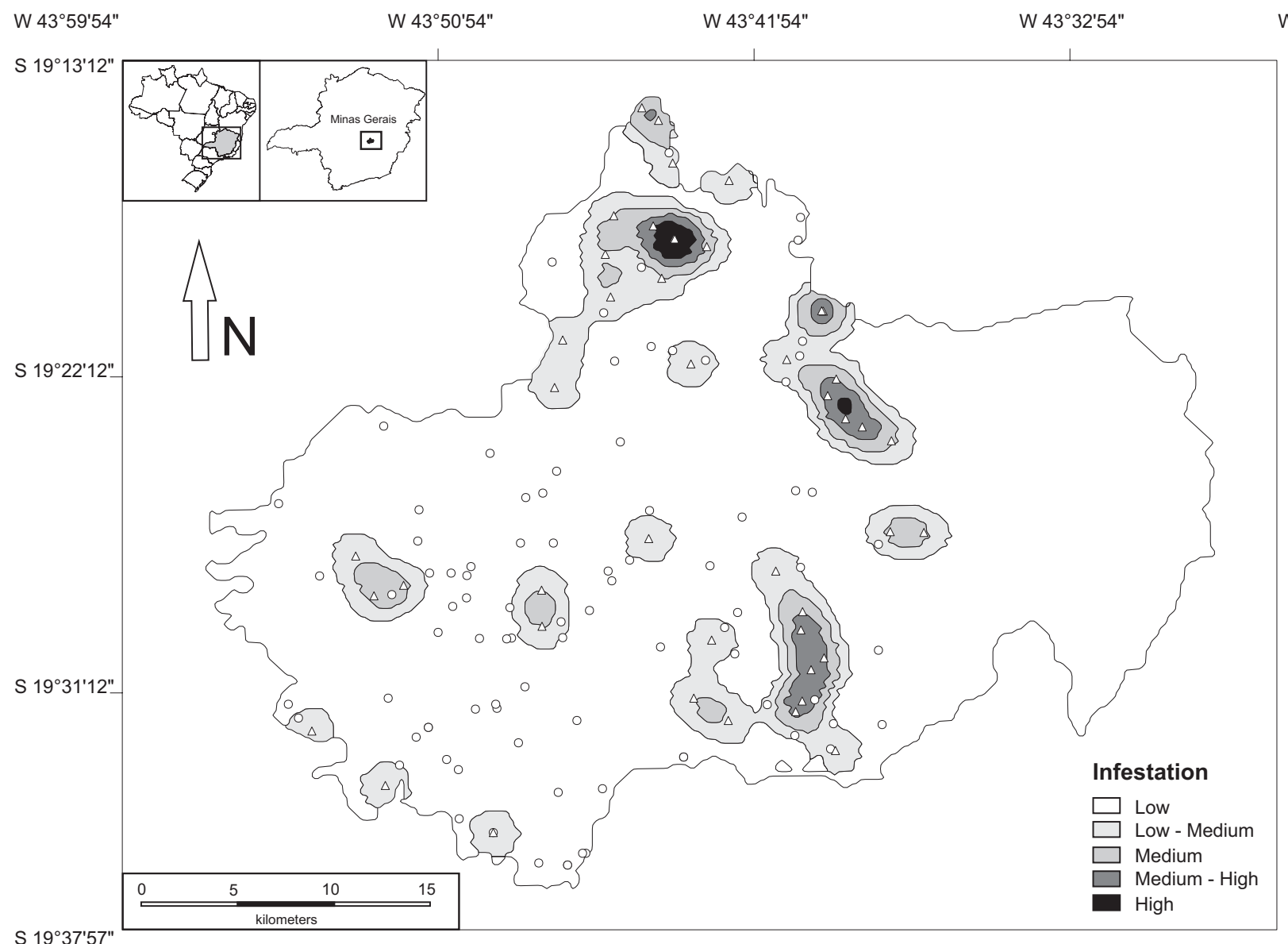

FIGURE 1 - Map of the Kernel distribution for localities infested ( $\Delta$ ) by Panstrongylus megistus in Jaboticatubas, Brazil from 2007 to 2010 . (o) $=$ localities not infested. 
TABLE 1 - Numbers and percentages of Panstrongylus megistus nymphs and adults captured by ecotope and colonization in Jaboticatubas, Brazil from September 2007 to September 2010.

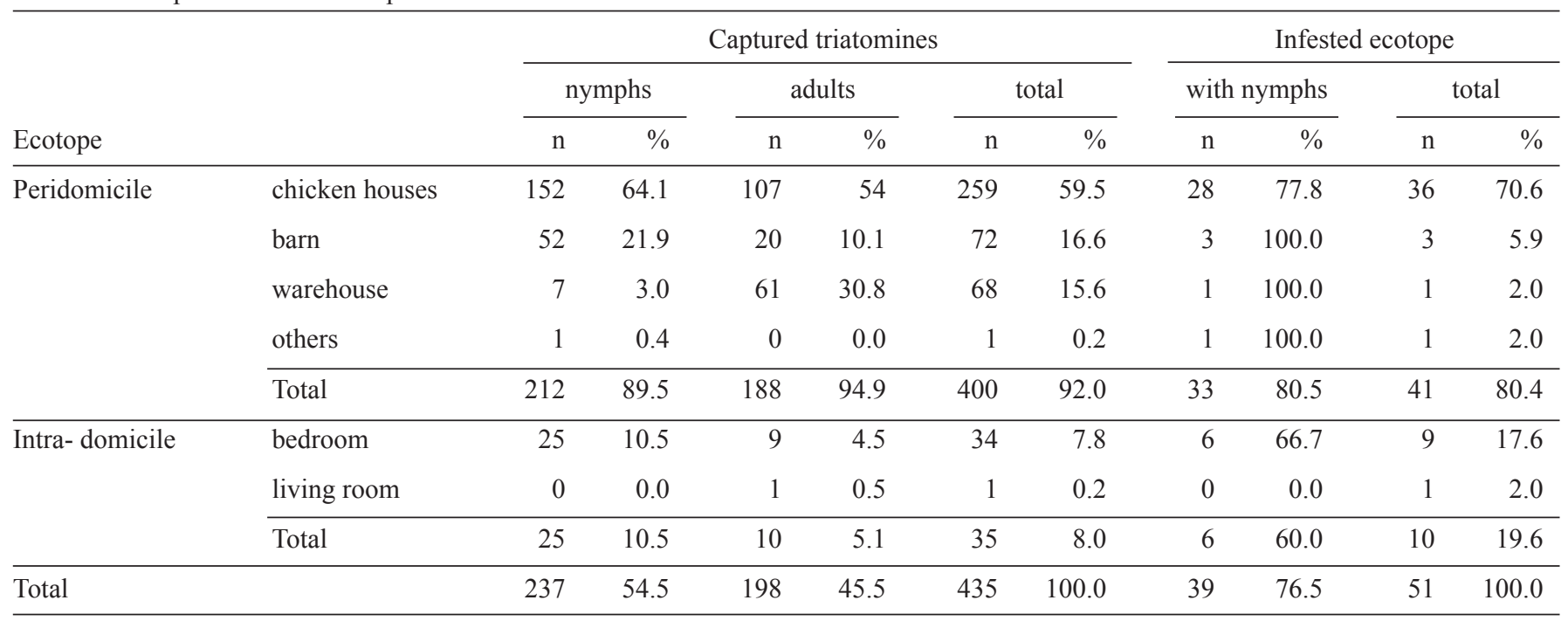

immature forms of this species inside well-structured houses. In addition to highlight the process of domiciliation in the region, this observation also indicates the pressure of $P$. megistus colonization, even in organized artificial biotopes. Thus, it should be noted that house improvements are insufficient to control the reinfestation of this species ${ }^{5}$, but such improvements may be important to limit insect density in houses.

The other triatomine species captured was T. sordida, which was exclusively observed in chicken houses and with no infection by trypanosomatids, confirming its ornithophilic behavior in this area.

The process of reinfestation by $P$. megistus was observed five months after the spraying, and only nymphs were found. This reinfestation most likely occurred because of the remaining eggs hatching, as the insecticide used does not penetrate the egg shell. Alternatively, the eggs may have been beyond the reach of the insecticide, preventing contact with the nymph after hatching. It is also worth considering that $P$. megistus has an annual cycle ${ }^{14}$.

Of the 44 infested locations, only three localities were infested in three cycles of captures, and all locations were infested by $P$. megistus, which indicates that vector control in the City of Jaboticatubas is indeed effective.

The strong association of $P$. megistus with chickens coincides with the data reported by Villela et al. ${ }^{5}$ and Paula et al. ${ }^{15}$ for the State of Minas Gerais. Due to the availability of food sources, wild triatomines are attracted to the peridomicile environment, which is a very important environment for maintaining the infestation of the household and can be the source of infestation for the house interior ${ }^{5}$. Hence, the peridomicile becomes the focus of control and is hampered by the complexity of the surroundings and the rapid degradation of insecticide in this type of environment.

In 2006, Brazil was certified for the interruption of vectorial transmission by Triatoma infestans ${ }^{12}$. Unfortunately, this great achievement was confused with the elimination of transmission of T. cruzi, resulting in serious consequences for the PCDC, which has been neglected in the country, mainly due to low levels of human transmission, the emergence of other diseases and political and administrative issues. Fortunately, this confusion did not occur in Jaboticatubas, where insect control was maintained.

The characteristics of triatomine infestation described in this work point to P. megistus as the main $\mathrm{CD}$ vector species in Jaboticatubas. These good results are a consequence of the control program activities, and it is essential to follow up these control actions, with special attention paid to the areas with the greatest concentrations of infested locations, as indicated by the Kernel method.

Finally, it is important to consider the current scenario of the City of Jaboticatubas. In addition to the discussed issues, the city has unusual natural beauty and is thus experiencing a large amount of real estate speculation due to increased interest in investing in tourism. Several condominium homes have been planned, creating a major environmental impact. In the process of urbanization, it is possible to observe the human action in the modification of vegetation, with large areas of pastures and crops being affected in almost the entire municipality, with the exception of the protected areas of the east and the gallery forests. These areas constitute the main refuges of $P$. megistus, where insects can spread to colonize artificial environments. Thus, this region deserves special attention when considering control of $\mathrm{CD}$ and other anthropozoonoses.

\section{ACKNOWLEDGMENTS}

We acknowledge the Municipal Health Department of Jaboticatubas and the health agents who greatly contributed to this work. 


\section{CONFLICT OF INTEREST}

The authors declare that there is no conflict of interest.

\section{FINANCIAL SUPPORT}

CNPq - Conselho Nacional de Desenvolvimento Científico e Tecnológico (Edital Universal, Process number 476352/20088) and Centro de Pesquisas René Rachou, Fundação Oswaldo Cruz, State of Minas Gerais, Brazil.

\section{REFERENCES}

1. Corrêa RR, Silva EOR, Schiavi A. Observações sobre o Panstrongylus megistus, transmissor da moléstia de Chagas (Hemiptera, Reduviidae). Arq Hig Saude Publica 1963; 28:165-174.

2. Silveira AC. Entomological survey (1975-1983). Rev Soc Bras Med Trop 2011; 44 (supl II):26-32.

3. Patterson JS, Barbosa SE, Feliciangeli MD. On the genus Panstrongylus Berg 1879: evolution, ecology and epidemiological significance. Acta Trop 2009; 110:187-199.

4. Dias JCP. Doença de Chagas em Bambuí, Minas Gerais, Brasil. Estudo clínico-epidemiológico a partir da fase aguda, entre 1940 a 1982 [Doctorate Thesis]. Belo Horizonte: Universidade Federal de Minas Gerais; 1982.

5. Villela MM, Souza JM, Melo VP, Dias JC. Evaluation of the Chagas Disease Control Program and presence of Panstrongylus megistus in central-western Minas Gerais State, Brazil. Cad Saude Publica 2009; 25:907-917.
6. Santos VR, Yokoo EM, Souza-Santos R, Atanaka-Santos M. Fatores socioambientais associados à distribuição espacial de malária no assentamento Vale do Amanhecer, Município de Juruena, Estado de Mato Grosso, 2005. Rev Soc Bras Med Trop 2009; 42:47-53.

7. Cook-Mozaffari PJ. Mortality and incidence data suitable for geographical analysis by "small" areas. In: Elliott P, editor. Methodology of Enquiries into Disease Clustering. London: London School of Hygiene and Tropical Medicine; 1988. p. 7-16.

8. Ministério Saúde, Superintendência de Campanhas de Saúde Pública, Divisão de Doença de Chagas. Inquérito Sorológico: Prevalência por Município. Brasília: Centro de Documentação do Ministério da Saúde; 1980 .

9. Instituto Brasileiro de Geografia e Estatística [Internet]. 2011 [Cited 2011 November 28]. Available from: http://www.ibge.gov.br.

10. Superintendência de Campanhas de Saúde Pública, Divisão de Doença de Chagas. Manual de Normas Técnicas da Campanha de Controle da Doença de Chagas. Brasília, DF: Ministério da Saúde; 1980.

11. Bailey TC, Gatrell AC. Interactive spatial data analysis, $1^{\text {st }}$. ed. Essex: Longman Group Limited; 1995.

12. Dias JC. Chagas disease: successes and challenges. Cad Saude Publica 2006; 22:2020-2221.

13. Portaria $n^{\circ}$. 1.399. Regulamenta a NOB SUS $01 / 96$ no que se refere às competências da União, estados, municípios e Distrito Federal, na área de epidemiologia e controle de doenças, define a sistemática de financiamento e dá outras providências. Diário Oficial da União; 1999.

14. Dias JC, Dias E. Chagas' disease. General findings in 67 cases of acute Chagas' disease observed by the graduate Dr. Emmanuel Dias (Oswaldo Cruz Institute), Bambuí, MG from 1955-67. Hospital (Rio J) 1968; 73:1935-1945.

15. Paula MB, Costa IN, Freitas PA, Limongi JE, Pajuaba Neto AA, Pinto RM, et al. Occurrence of positivity for Trypanosoma cruzi in triatomine from municipalities in Southeastern Brazil, from 2002 to 2004. Rev Soc Bras Med Trop 2010; 43:9-14. 